\title{
Table of adjudications of the media regulators
}

\section{IPSO}

Bobin v The Times, Complaint 01657-14

(26 March 2015)

\section{PRESS COMPLAINTS COMMISSION (PCC)}

A Woman v Loaded (11 May 2010) ... 74 Councillor Moherv Brent and Kilburn Times (30 May 2014) .75
Sue Slater v Nelson Leader (9 August 2012) 76

Goble v The People (29 September 2009) 79

Minogue v Daily Mirror and Daily Record (28 January 2010) 80

Mullan, Weir and Campbell v Scottish Sunday Express (22 June 2009) 80

The family of Alice Claypoole $v$ Daily Mirror (2005) 80 